Mexican Journal of Biotechnology 2018, 3(3):1-14

Journal homepage:www.mexjbiotechnol.com

ISSN:2448-6590

ORIGINAL RESEARCH

\title{
Effect of culture media and silver nitrate concentration on nanoparticle biosynthesis by a filamentous fungus
}

\section{Efecto del medio de cultivo y concentración de nitrato de plata sobre la biosíntesis de nanopartículas por un hongo filamentoso}

Diana G. Alamilla-Martínez, Norma G. Rojas-Avelizapa, Iván Domínguez-López, José D.O Barceinas-Sánchez, Marlenne Gómez-Ramírez*

Departamento de Biotecnología, Centro de Investigación en Ciencia Aplicada y Tecnología Avanzada del Instituto Politécnico Nacional, Querétaro, México.

*Corresponding author.

E-mail address: mgomezr@ipn.mx (M. Gómez-Ramírez).

Article history:

Received: 16 December 2017 / Received in revised form: 9 April 2018 / Accepted: 28 April 2018 / Published online: 1 July 2018.

https://doi.org/10.29267/mxjb.2018.3.3.1

\begin{abstract}
Recently the demand in the development of eco-friendly nanoparticles as alternative to chemical and physical methods has been increasing so the aim of this study was to evaluate the effect of silver nitrate concentration and extracellular filtrate (EF) produced by a filamentous fungus isolated from a spent catalyst and coded e identified as Penicillium purpurogenum CATMC-AH-1 on Silver nanoparticles (AgNPs) production. The filamentous fungus was growth in two culture media named Sucrose and Czapeck media to produce biomass and its was put in contact with water to get two different extracellular filtrates called EFS (extracellular filtrate sucrose) and EFC (extracellular filtrate Czapeck), the $\mathrm{EF}$ has the molecules involved to synthesis and stabilization of AgNPs. Three concentrations of $\mathrm{AgNO}_{3} 1,1.5$ and $2 \mathrm{mM}$ and both extracellular filtrates were used to produce AgNPs. The AgNPs produced were monitored by UV-visible absorption spectra from 200 to $800 \mathrm{~nm}$ while their morphology and size were identified by Transmission Electron Microscopy (TEM) and software analysis SPIP 2.6.0. Results showed that both extracellular filtrates had the ability to produce AgNPs with the three concentrations of $\mathrm{AgNO}_{3}$ used. TEM analysis showed AgNPs with spherical morphology in all systems. The AgNPs synthesized in EFS with the three $\mathrm{AgNO}_{3}$ concentrations showed average sizes of 8.9, 8.4 and $6.7 \mathrm{~nm}$ respectively. From EFC, the average sizes of AgNPs were of 14.9, 11.5
\end{abstract}


and $10.1 \mathrm{~nm}$ respectively. In summary, in EFS smallest sizes and diameter dispersion of AgNPs were obtained, comparing to EFC and the spherical shape was similar in both filtrates. The $\mathrm{AgNO}_{3}$ concentration had a positive effect when the $\mathrm{EFC}$ filtrate was used since a direct correlation was observed between the concentrations of silver nitrate and increase the absorption band around $420 \mathrm{~nm}$ as result of surface plasmon resonance of AgNPs produced. The AgNPs biosynthesized from both EF (EFS and EFC) could be used as antimicrobial agent by their small size. Parameter as silver nitrate concentrations and culture media are important because could be affect the size and concentrations of AgNPs biosynthesized.

Keywords: AgNPs, biosynthesis, extracellular filtrate, surface resonance plasmon.

\section{RESUMEN}

La Reciente demanda en el desarrollo de nanopartículas ecológicas como una alternativa a los métodos químicos y físicos ha ido en aumento, dado lo anterior el objetivo de este estudio fue evaluar el efecto de la concentración de nitrato de plata y el filtrado extracelular (FE) producido por un hongo filamentoso aislado de un catalizador agotado e identificado como Penicillium purpurogenum CATMC-AH-1 en la producción de nanopartículas de plata (AgNPs). El hongo filamentoso fue cultivado en dos medios de cultivo Sacarosa y Czapeck para producir la biomasa la cual fue puesta en contacto con agua para obtener los dos diferentes filtrados extracelulares llamados FES (filtrado extracelular sacarosa) y FEC (filtrado extracelular Czapeck), el filtrado extracelular contiene las moléculas implicadas en la síntesis y estabilización de las AgNPs. Tres concentraciones de $\mathrm{AgNO}_{3}$ 1, 1.5 y 2 mM y ambos filtrados extracelulares fueron usados para producir las AgNPs. Las AgNPs producidas fueron monitoreadas mediante su espectro de absorción UV-Vis de 200 a 800 nm mientras que su forma y tamaño fueron identificados por microscopía electrónica de transmisión (MET) y analizados con el software SPIP 6.2.0. Los resultados mostraron que ambos filtrados extracelulares tuvieron la habilidad para producir AgNPs en las tres concentraciones de $\mathrm{AgNO}_{3}$. El análisis en MET mostró AgNPs con morfología esferoide en todos los sistemas. Las AgNPs sintetizadas en el FES en las tres concentraciones de $\mathrm{AgNO}_{3}$ mostraron tamaños promedio de 8.9, 8.4 y $6.7 \mathrm{~nm}$ respectivamente. En los FEC, los tamaños promedio de AgNPs fueron de 14.9, 11.5 y $10.1 \mathrm{~nm}$ respectivamente. En resumen, en el FES se obtuvo una menor dispersión del diámetro y tamaños más pequeños en comparación con el FEC, siendo la forma esférica similar para ambos filtrados. La concentración de nitrato de plata tuvo un efecto positivo cuando se empleó el filtrado FEC observando una correlación directa entre la concentración del nitrato de plata y el incremento en la intensidad de las bandas de absorción alrededor de los $420 \mathrm{~nm}$ como resultado de la resonancia del plasmón de superficie de las AgNPs producidas. Las AgNPs bio-sintetizadas tanto en el FES y FEC podrían ser empleadas como agentes antimicrobianos por su tamaño pequeño. Parámetros como concentración de nitrato de plata y medio de cultivo son importantes porque podrían afectar el tamaño y la concentración de AgNPs bio-sintetizadas. 
Palabras clave: AgNPs, biosíntesis, filtrado extracelular, resonancia del plasmón superficial.

\section{INTRODUCTION}

Silver nanoparticles have attract increasing attention for the wide range of applications in biomedicine. Silver nanoparticles, generally smaller than $100 \mathrm{~nm}$ and have distinct physical, chemical and biological properties compared to their bulk parent materials. The optical, thermal, and catalytic properties of silver nanoparticles are strongly influenced by their size and shape (spherical, plate, triangular, cylindric, hexagonal) Additionally, owning to their broad-spectrum antimicrobial ability against clinically important bacteria, pathogenic fungi to humans, animals and plants. Silver nanoparticles have also become the most widely used sterilizing nanomaterials in consuming and medical products, for instance, textiles, food storage bags, refrigerator surfaces, and personal care products (Wei et al., 2015; Siddiqi \& Husen 2016). Their synthesis can be carry out by physical-chemical or biological methods although the process production is in some cases, more timeconsuming in comparison with the physical-chemical methods. In the first case, harmful substances are used or high-level energy are consumed, meanwhile the biological methods use enzymes, plant extracts, bacteria, yeast and filamentous fungi are used, these methods are considered ecofriendly (Selvam et al., 2017). Enzymes as NADH or NADPH dependent reductases, proteins with free amino and carboxyl groups, phytochelatins and other metabolites as anthraquinones and naphtaquinones have been reported as molecules involved in the biosynthesis process (Moghaddam et al., 2015). Depending nature of synthesis nanoparticles will have different characteristics, AgNPs produce by biological synthesis has stability in aqueous matrices and biocompatibility, which makes them potential candidates to be used in biological systems (Singh et al., 2016). The extracellular biosynthesis by filamentous fungi offers advantages over intracellular biosynthesis due at the first case, the cellular lysis and purification process is omitted, among the fungi reported with the ability to produce AgNPs extracellularly are Aspergillus fumigatus, Aspergillus flavus, Aspergillus niger, Fusarium oxysporum, Fusarium spp, Trichoderma reesei, Trichoderma viride, Trichoderma asperellium, Penicillium fellutanum, Neurospora crassa, Cladosporium cladosporioides, Rhizopus stolonifer and Alternaria alternata (Moghaddam et al., 2015;Singh et al., 2016). The shape and size can vary according to the production conditions such as time, $\mathrm{pH}$, temperature, age fungi, $\mathrm{AgNO}_{3}$ concentration, culture media and microorganism., however in most cases spherical shape is reported for AgNPs. The main objective of the present research was to evaluate the effect of two culture media, Sucrose and Czapeck, in the biomass production used to obtain the extracellular filtrates, as well as the effect of the $\mathrm{AgNO}_{3}$ concentration over the shape and the size of the AgNPs synthetized by a filamentous fungus isolated from a spent catalyst of petrochemical industry. 


\section{MATERIALS AND METHODS}

\subsection{Microorganism}

The filamentous fungus was isolated previously from a spent catalyst from petrochemical industry and was coded as CATM-AH-1 and was identified microscopically by the use of the moist chamber technique, an in situ technique to study fungi.

\subsection{Biomass production and obtention of extracellular filtrates}

The filamentous fungus was cultivated on potato dextrose agar plates and was kept at $30^{\circ} \mathrm{C}$ until sporulation. The conidia suspension of fungus was determined in a Neubauer chamber. To obtain biomass, two liquid media, sucrose medium with composition in $\mathrm{g} / \mathrm{L}$ is: 100 , sucrose; $1.5, \mathrm{NaNO}_{3} ; 0.5, \mathrm{KH}_{2} \mathrm{PO}_{4} ; 0.025, \mathrm{MgSO}_{4} .7 \mathrm{H}_{2} \mathrm{O} ; 0.025, \mathrm{KCl} ; 1.6$, yeast extract (Aung \& Ting 2005) and Czapeck media consisting in $\mathrm{g} / \mathrm{L} .1,0, \mathrm{~K}_{2} \mathrm{HPO}_{4} ; 3.0$, $\mathrm{NaNO}_{3} ; 0.5, \mathrm{MgSO}_{4} \cdot 7 \mathrm{H}_{2} \mathrm{O} ; 0.5, \mathrm{KCl} ; 0.01, \mathrm{FeSO}_{4} \cdot 7 \mathrm{H}_{2} \mathrm{O} ; 30.0$, sucrose (Deng et al., 2013). Four $500 \mathrm{~mL}$ Erlenmeyer flasks containing $100 \mathrm{~mL}$ of each medium were inoculated with fungus conidia to get $3 \times 10^{5}$ conidia $/ \mathrm{mL}$ and incubated at $30^{\circ} \mathrm{C}, 150 \mathrm{rpm}$ during 5 days for biomass production. Subsequently, the biomass of each media is together and was separated by vacuum filtration through sterile fine-pore filter paper and washed three times with sterile distilled water. Finally, the excess of water was removed through vacuum filtration (Sandoval-Cárdenas et al., 2017). The extracellular filtrates were obtained after incubating $2 \mathrm{~g}$ of thrice washed biomass with $30 \mathrm{~mL}$ of sterile distilled water during $72 \mathrm{~h}$ at $30^{\circ} \mathrm{C}$ and $150 \mathrm{rpm}$ and recovering filtrate using fine-pore filter. These filtrates biomass free were named extracellular filtrates (reducing agent) of each biomass $200 \mathrm{~mL}$ of extracellular filtrates were obtained approximately.

\subsection{AgNPs synthesis}

Three experimental sets flasks of $125 \mathrm{~mL}$ containing $30 \mathrm{~mL}$ of extracellular filtrate were prepared for each reducing agent, all of them were incubated with extracellular filtrates plus $\mathrm{AgNO}_{3}$ to reach a final concentration of $1,1.5$ y $2 \mathrm{mM}$. Negative controls were prepared adding each reducing agent but not $\mathrm{AgNO}_{3}$. The experimental flasks were incubated during 3 days at $45^{\circ} \mathrm{C}$ and $150 \mathrm{rpm}$ at the end of incubation period, samples were monitored for color change and partially characterized by means of their UV-Visible spectra (SaldovalCardenas 2012; Abdelghany et al., 2018).

\subsection{UV-visible absorption}

The AgNPs biosynthesized were monitored for color change and partially characterized by their UV-Vis spectra from 200 to $800 \mathrm{~nm}$. The change in color from pale orange to brown and the increased absorbance at $420 \mathrm{~nm}$ is attributed to the surface plasmon (Vigneshwaran et al., 2007) resonance. 


\subsection{TEM characterization}

The morphology and size of AgNPs biosynthesized were determined using TEM, all samples were ultrasonically dispersed for six pulses of 15 seconds and one drop was deposited onto a $\mathrm{Cu}$-collodion-graphite grid and allowed to be air dried. The grid was then scanned employing a JEM10-10 an 80-kV transmission microscope located in ENCB-IPN. All micrographs were analyzed by using the software SPIP 6.0.2. Nine fields were analyzed per sample, and the particles analyzed were on average 250 .

\section{RESULTS}

\subsection{Fungus identification}

The isolated coded as CATMC-AH-1 was identified as Penicillium purpurogenum. the colony characteristics of the fungus on potato dextrose agar at $30^{\circ} \mathrm{C}$ were found to produce a olive green/bluish green color, velvety colony, with granular appearance with red pigmentation which spread as the fungus mycelia grew. Microscopic observation showed that the conidiophores are branched. The conidia are globules resembling glass beads (Gwa \& Abdulkadir., 2017), spectral anlysis (Fig 1B) shows that extracelular pigment was read araund of $500 \mathrm{~nm}$ (Méndez-Zavala et al., 2007).

\subsection{AgNPs production}

The production of AgNPs was carryout by using the extracellular filtrates sucrose and extracellular filtrate Czapeck plus $\mathrm{AgNO}_{3}$ concentrations at 1, 1.5 and $2 \mathrm{mM}$. The AgNPs productions was confirmed by UV-Vis absorption spectra from 200 to $800 \mathrm{~nm}$, showing an absorption band around of $420 \mathrm{~nm}$, indicating the presence of AgNPs, in comparison with the negative control that did not show that absorption band, this phenomenon is attributed to the surface resonance plasmon (Vigneshwaran et al., 2007), indicating maximum absorbance values of 0.97 units to AgNPs synthetized from EFS with the three $\mathrm{AgNO}_{3}$ different concentrations evaluated (Fig 1A). AgNPs from EFC showed absorbance values of 1.8, 2 and 2.1 units for 1, 1.5 and $2 \mathrm{mM}$ of $\mathrm{AgNO}_{3}$ respectively (Fig 1B). The absorption bands observed from 239 to $284 \mathrm{~nm}$ in figures 1 (A and B) could be attributed to aromatic groups of proteins that are present in the extracellular filtrates while that the band around of $350 \mathrm{~nm}$ could correspond to a reddish pigment produced by the fungus (Narsing-Rao et al., 2017). 

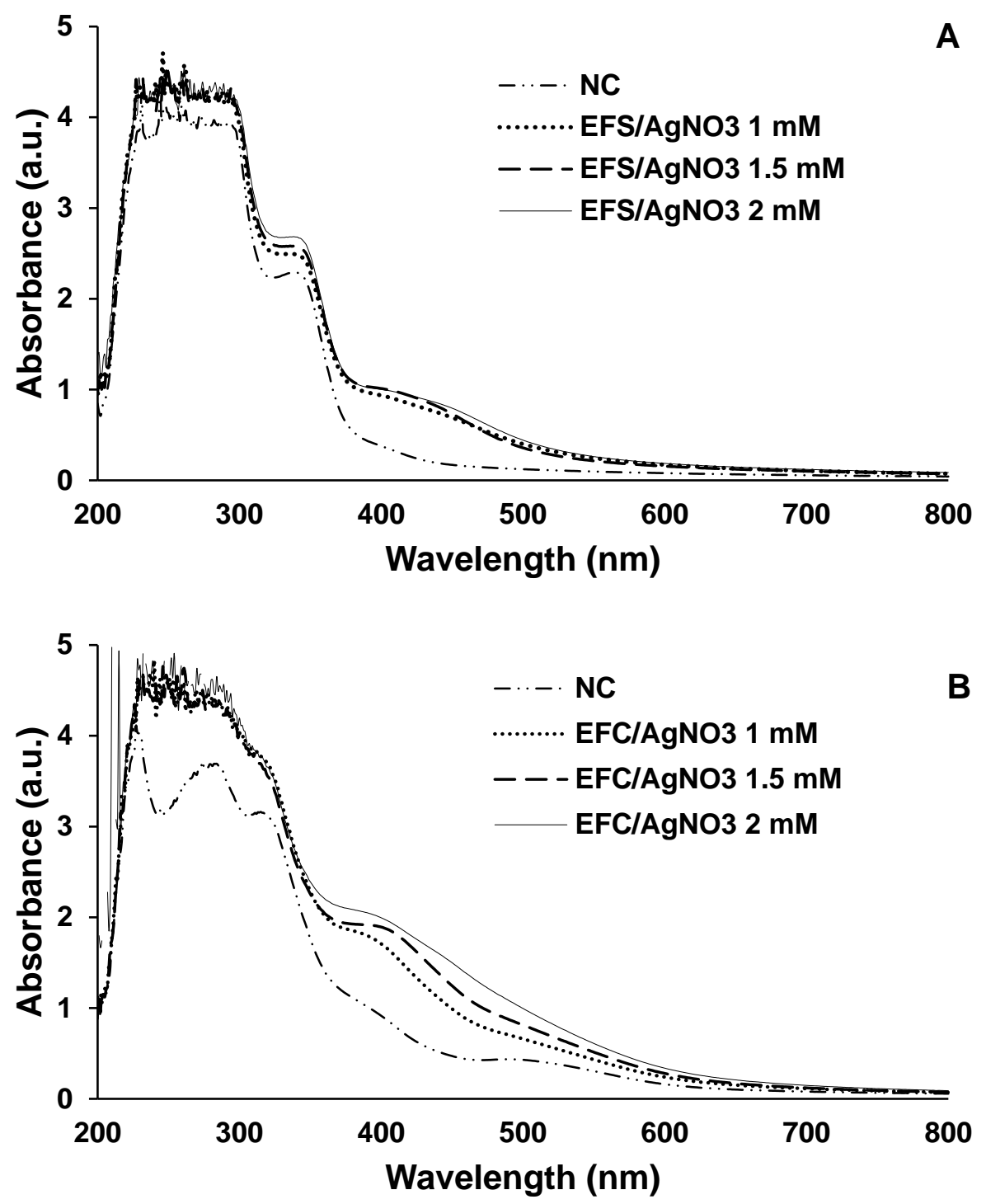

Fig. 1. UV-Vis absorption spectrum of (A) EFS and (B) $\mathrm{EFC}$ with $\mathrm{AgNO}_{3}$ at $1,1.5$ and 2 $\mathrm{mM}$ and the negative control (NC), incubated at $45^{\circ} \mathrm{C}$ during $72 \mathrm{~h}$ and $180 \mathrm{rpm}$ in darkness.

\subsection{Characterization of AgNPs}

Shape and size of AgNPs synthetized from extracellular filtrates EFS and EFC were determined by TEM and analyzed by the software SPIP 2.0.6. Micrograph analysis showed AgNPs polydisperse with spherical shape in all systems (Figs 2 and 3). The average size diameter of AgNPs in EFS was of 8.9, 8.4, $6.7 \mathrm{~nm}$ for $\mathrm{AgNO}_{3}$ concentration of 1, 1.5 and 2 $\mathrm{mM}$ respectively indicating a shape reduction when the substrate concentration increased. The total number of nanoparticles obtained in EFS had a size between 2-22 nm. The percentages obtained through the interval size $(2-7 \mathrm{~nm})$ and $\mathrm{AgNO}_{3}$ concentration employed were $37.4 \%, 45.89 \%$ and $66.1 \%$ for $1,1.5$ and $2 \mathrm{mM}$ of $\mathrm{AgNO}_{3}$ respectively; and $40.25 \%, 35.3 \%$ and $25.7 \%$ to interval of $7-12 \mathrm{~nm}$ and finally $22.3 \%, 19 \%$ and $8 \%$ to interval of $12-22 \mathrm{~nm}$ to the concentrations before mentioned (Fig 4). The average diameter 
of AgNPs synthetized from EFC was 14.9, 11.5 and $10.1 \mathrm{~nm}$ which corresponds to $\mathrm{AgNO}_{3}$ concentrations of $1,1.5$ and $2 \mathrm{mM}$, respectively, again a reduction in average size was showed when the substrate concentration was increased, however, it has been observed a major size dispersion of AgNPs in the EFC than in EFS. The total number of nanoparticles obtained in EFS had a size between 2-37 nm. The percentage of size found were 13\%, 27\% and $35 \%$ for the size between 2-7 nm which corresponded to 1, 1.5 and $2 \mathrm{mM}$ of $\mathrm{AgNO}_{3}$; $28 \%, 36 \%$ and $35 \%$ for $7-12 \mathrm{~nm}$ respectively and $59 \%, 37 \%$ and $30 \%$ for size within $12-$ $37 \mathrm{~nm}$ (Fig 5). Therefore, it can be observed that in EFS, average sizes of AgNPs were smaller than in EFC at the same tested substrate concentrations. The major percentage of smallest AgNPs (2-7 nm) was obtained when using the $\mathrm{AgNO}_{3}$ concentration of $2 \mathrm{mM}$ for both filtrates for EFS and EFC, respectively.

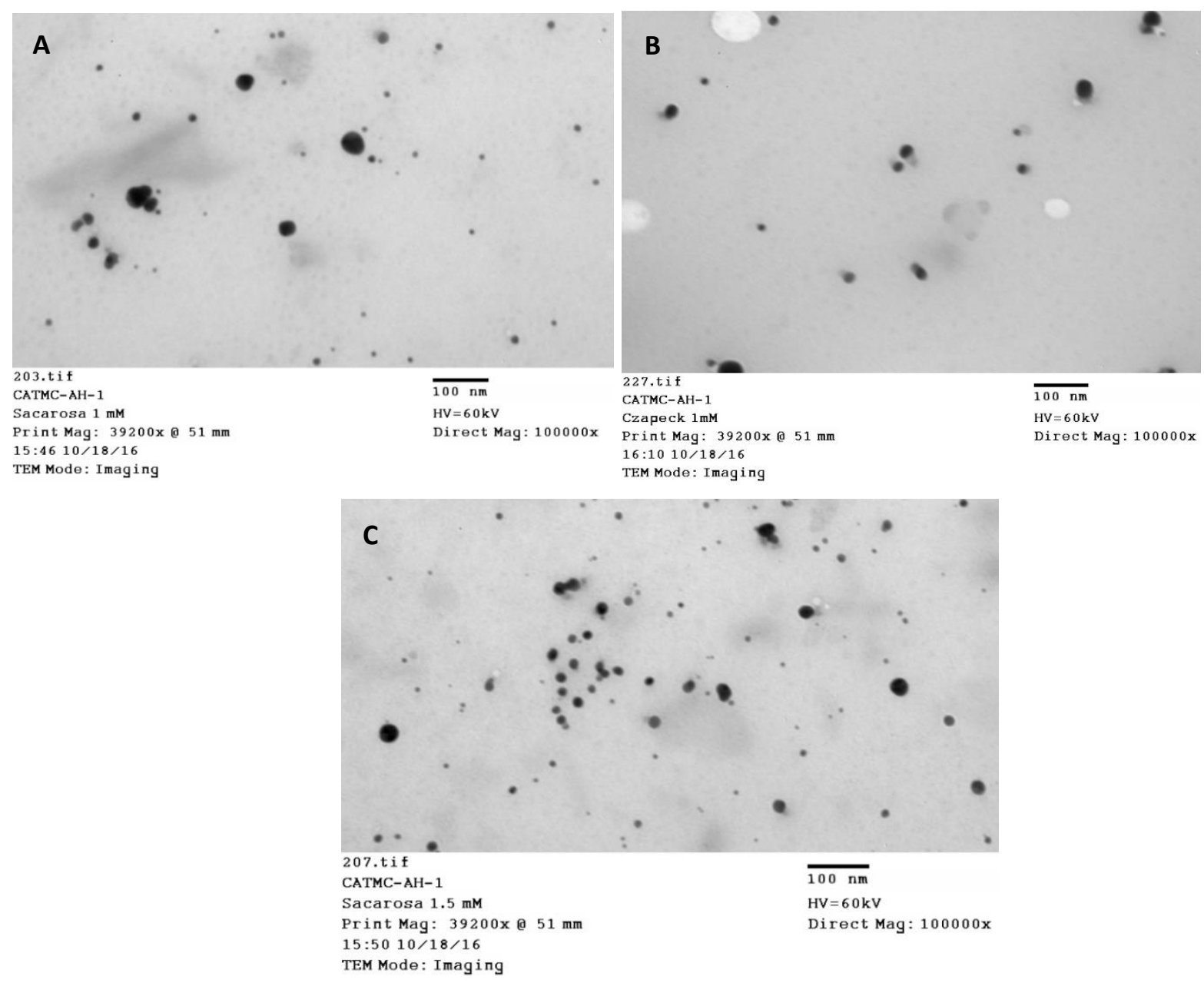

Fig. 2. AgNPs synthetized by fungus CATMC-AH-1 from EFS and $\mathrm{AgNO}_{3}$ concentration of $1 \mathrm{mM}(\mathrm{A}), 1.5 \mathrm{mM}(\mathrm{B})$ and $2 \mathrm{mM}$ (C) incubated during $72 \mathrm{~h}$ in darkness. 

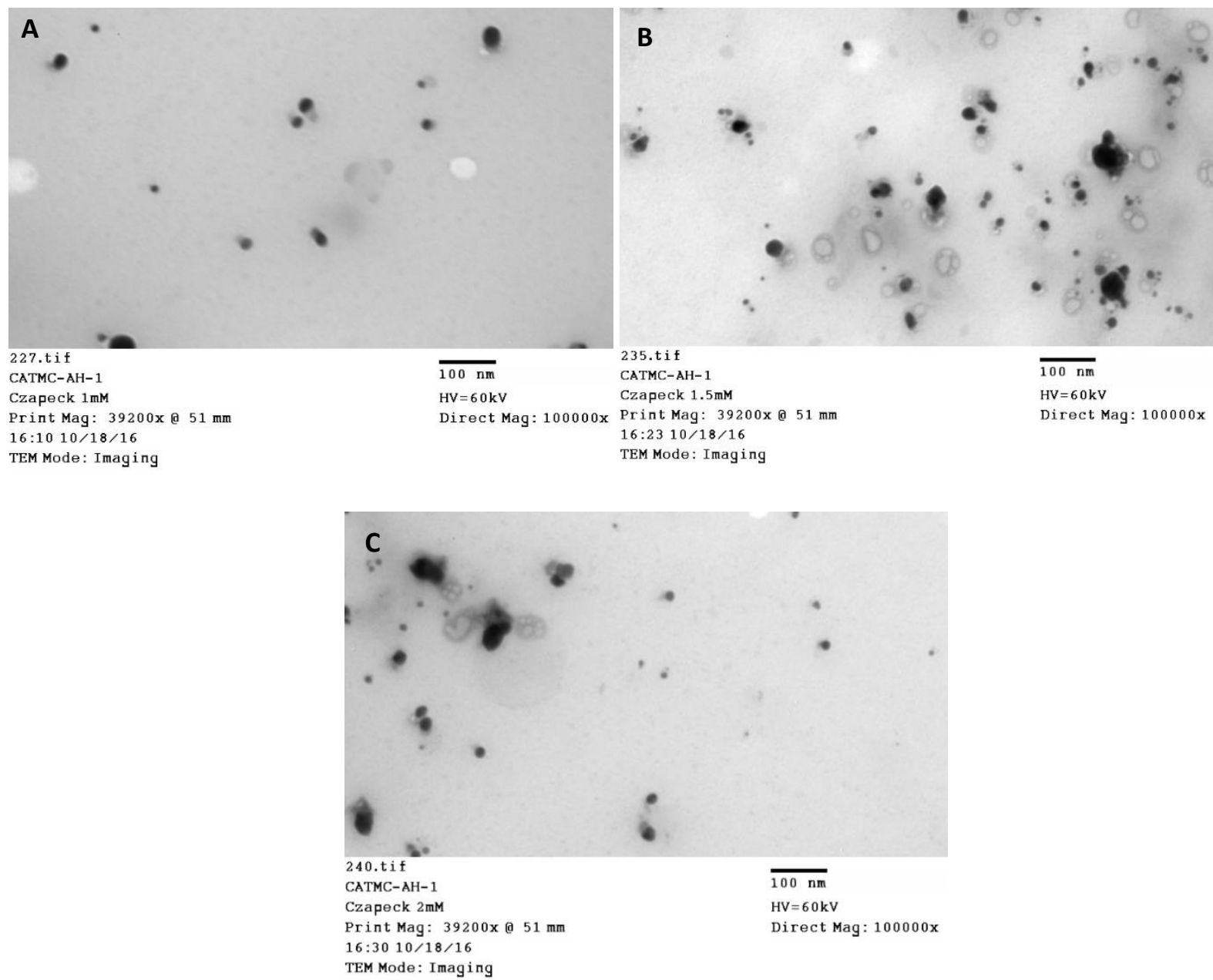

Fig. 3. AgNPs synthetized by fungus CATMC-AH-1 from $\mathrm{EFC}$ and $\mathrm{AgNO}_{3}$ concentration of $1 \mathrm{mM}(\mathrm{A}), 1.5 \mathrm{mM}(\mathrm{B})$ and $2 \mathrm{mM}(\mathrm{C})$ incubated during $72 \mathrm{~h}$ in darkness. 


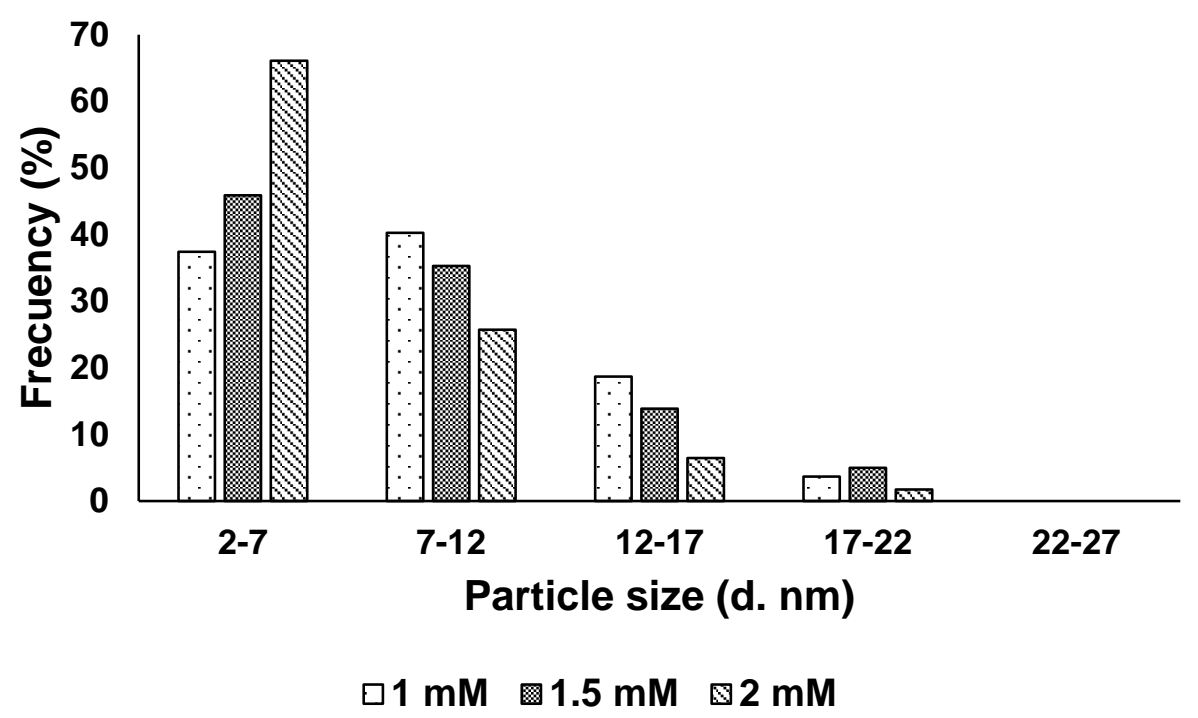

Fig. 4. Size distribution of the AgNPs synthesized for extracellular filtrate sucrose at 1, 1.5 and $2 \mathrm{mM}$ of $\mathrm{AgNO}_{3}$, incubated at $45^{\circ} \mathrm{C}, 180 \mathrm{rpm}$ in darkness during $72 \mathrm{~h}$.

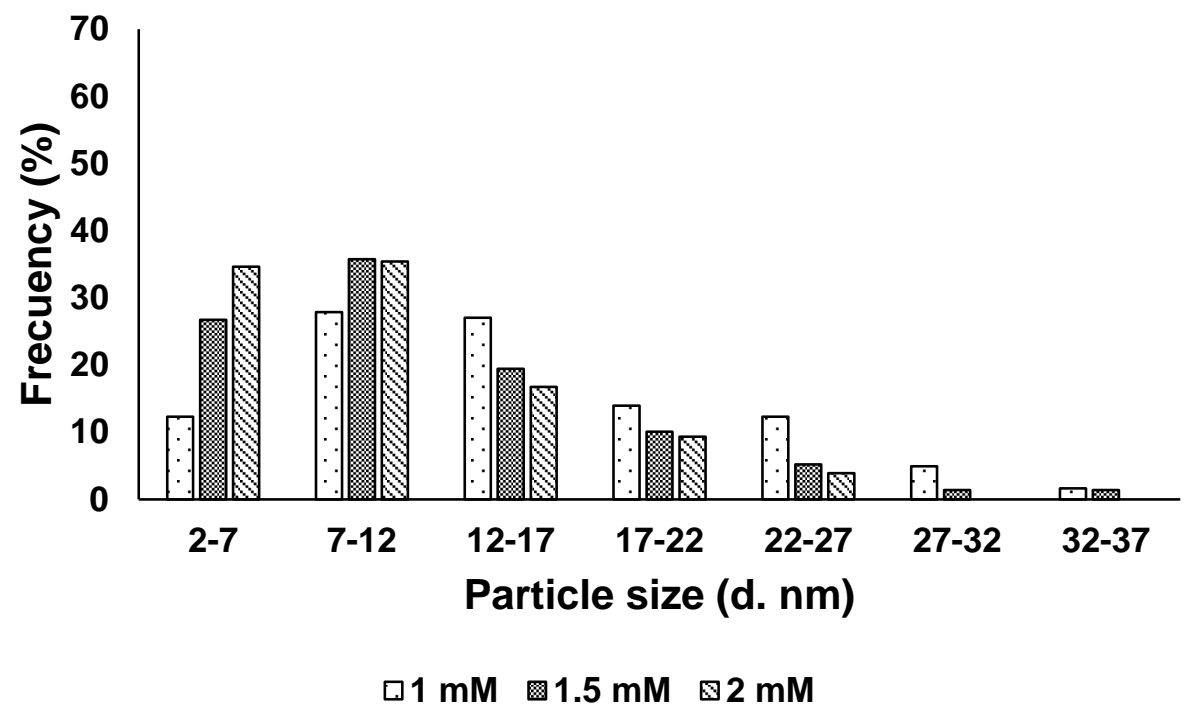

Fig. 5. Size distribution of the AgNPs synthesized for extracellular filtrate Czapeck at 1, 1.5 and $2 \mathrm{mM}$ of $\mathrm{AgNO}_{3}$, incubated at $45^{\circ} \mathrm{C}, 180 \mathrm{rpm}$ in darkness during $72 \mathrm{~h}$. 


\section{DISCUSION}

In the recent past, silver nano particles (AgNps) have received enormous attention of the researchers due to their extraordinary defense against wide range of microorganisms. The exceptional characteristics of AgNPs have made them applicable in various fields like biomedical, drug delivery, water treatment, agricultural, sensor, textiles, food, health care, antiinsectal etc (Abdelghany et al., 2018). Many routes have been introduced for the synthesis of silver nanostructures, which can be categorized as: (i) chemical methods; (ii) physical methods, and (iii) biological methods. Chemical methods for the syntheses of silver nanostructures in solution usually contains three main components: metal precursors, reducing agents, and stabilizing/capping agents. Widely used reducing agents include borohydride, sodium citrate, ascorbic acid, alcohol, and hydrazine compounds. By contrast, physical methods do not involve toxic chemicals and usually have fast processing time. Another advantage of physical methods is that the AgNPs formed have a narrow size distribution; however, a major drawback is their high energy consumption. In the biological synthesis of AgNPs, the toxic reducing agents and stabilizers are replaced by nontoxic molecules (proteins, carbohydrates, antioxidants, etc.) produced by living organisms, including bacteria, fungi, yeasts, and plants (Wei et al., 2015). The AgNPs synthesis by microbes is strenuous compared to the use of plant extracts and biopolymers as reducing and capping agents mainly due to the difficulty in growth, culture maintenance, and inoculums size standardization. Several fungal and bacterial species have been successfully used in the synthesis of AgNPs. The AgNPs synthesis mainly follow one of the two distinct routes, one utilizing extracellular materials secreted in the growth medium whereas the other utilizing microbial cell biomass directly. However, extracellular AgNP synthesis is been widely reported (Srikar et al., 2016). In the first case, the biosynthesis of metal nanoparticles by fungus, the fungus mycelium is exposed to the metal salt solution, in this condition the fungus produce enzymes and metabolites for own survival. In this process the toxic metal ions are reduced to the none-toxic metallic solid nanoparticles through the catalytic effect of the extracellular enzyme and metabolites of the fungus. By another hand it's demonstrated that using the dissimilatory properties of an eukaryotic organism such as fungi may be used to biosynthesize nanoparticles. It is shown that certain fungi have the ability of producing extracellular metabolites that serve as agent for their own survival when exposed to such environmental stresses like toxic materials (such as metallic ions), predators and temperature variations (Vahabi et al., 2011) or carbon starvation in this condition a decrease in biomass is induced, release of ammonium and production of cell wall hydrolytic enzymes, proteases and extracellular material is released (Ellstrom et al., 2015). Enzymes as hydrogenases, nitrate reductases or naphthoquinones and anthraquinones with excellent redox properties has been reported that could act as electron shuttle in metal reductions and producction of nanoparticles (Moghaddam et al., 2015). In our study the ability of AgNPs synthesis by two extracellular filtrates named EFS and EFC has been attributed to the action of proteins and enzymes which are excreted by the fungal mycelium when it's put in contact with only water and incubated at $30{ }^{\circ} \mathrm{C}$ during $72 \mathrm{~h}$. The type and amount of excreted molecules can be influenced by the nature of the culture media where the fungal mycelium was produced since the activation of the metabolic pathway required for the utilization of the nutrients present in the culture media depends on this, in our study culture media Sucrose and Czapeck were employed to obtained the fungal biomass, the Czapeck media is a synthetic medium, containing sucrose as carbon source 
and nitrate as the sole source of nitrogen in comparing with Sucrose media whose is a semisynthetic medium, containing sucrose as carbon source and yeast extract as source of nitrogen and carbon (Aung \& Ting 2005; Deng et al., 2013) as a result, the fungal biomass obtained in the Czapeck media was lower $(3 \mathrm{~g} / 100 \mathrm{~mL})$ comparing with sucrose media (5 $\mathrm{g} / 100 \mathrm{~mL}$ ). The fungal biomass gets in a stress state when it is put in contact only with water because of its carbon starvation it's begins to excrete biomolecules (Nitsche et al., 2012; Ellstrom et al., 2015), some of them can be involved in the AgNPs biosynthesis process. Reports indicate that one of the principal molecules that participates in this process are nitrate reductase enzymes while the molecules that stabilize the nanoparticles are proteins (Moghaddam et al., 2015). AgNPs synthesis is evidenced by the presence of an absorption band around of $420 \mathrm{~nm}$, which is characteristic of this type of material and is attributed to the surface plasmon resonance, the intensity of absorbance of this band is related, in some cases, with AgNPs concentration (Vigneshwaran et al., 2007), other factors that can influence in the intensity and width band are the shape, size, and cover of the nanoparticle (Zhang et al., 2016). The biosynthesized AgNPs from the EFS showed no difference in the intensity of absorption when the different $\mathrm{AgNO}_{3}$ concentrations were used, compared to the synthesized from EFC that showed an increase in the intensity of the band as the substrate concentration increased, which suggests that one of the molecules involved in the synthesis of these nanomaterials is of protein nature since the product (AgNPs) is affected by the substrate concentration $\left(\mathrm{AgNO}_{3}\right)$. It is known that the production of enzymes and proteins is influenced by the nutritional conditions in which the microorganism is grown, and that the production of AgNPs is influenced by the amount of substrate available (Singh et al., 2013), therefore, the increase in the absorption bands in the EFC samples is attributed to a higher concentration of nanoparticles that were synthesized by the action of the enzyme and / or metabolites with the ability to reduce the $\mathrm{Ag}^{+}$ions when encountering with a higher concentration of substrate. On the other hand, in EFS there was no increase in the bands when the substrate concentration increased, it could be originated by a substrate saturation since the enzyme can possibly be in a lower concentration since there is a greater amount of substrate than the enzyme is capable to use, this saturates the active site causing an inhibition of the enzymatic activity, causing probably the AgNPs to be smallest (Ariga et al., 2013; Korbekandi et al., 2013). For the applications of the AgNPs, some physicochemical properties of AgNPs, including size (surface area), shape, surface charge and coating, agglomeration, and dissolution rate, are particularly important for determining their biological interactions and impacts. Smaller particles have a larger surface area and, therefore, have greater toxic potential (Wei et al., 2016), which are affected by the conditions of production (Husseiny et al., 2015). In this work, was demonstrated for the first time, how the culture media where was obtained the fungal biomass used to get the extracellular filtrates have an influence on the percentage and size distribution of the biosynthesized AgNPs, since synthesis conditions such as time, temperature, agitation and substrate concentration were the same for both systems. Further, the high specificity of biomolecules involved in the biosynthesis process may enable an efficient control of AgNPs size and shape, whose tight control is critical to optimize applications. The percentages of the AgNPs of small size $(2-7 \mathrm{~nm})$ were higher in the EFS in comparison to the EFC, in both systems it can be observed that as the concentration of substrate increases $\left(\mathrm{AgNO}_{3}\right)$ the percentage in the interval of sizes of $2-7 \mathrm{~nm}$ increases, as for the shape of the particles, spheroidal AgNPs were observed in all cases. With respect to the possible applications that can be given to the AgNPs obtained by their characteristics, 
its use as antimicrobial agents is attractive, several studies have been related to the antimicrobial effect of the AgNPs and it has been found that the smaller AgNPs have a greater effect than larger ones (Raza et al., 2016), since the former have a larger contact surface and therefore are more toxic (Wei et al., 2016; Zhang et al., 2016), they also have a great easiness of traversing cell structures. It has been mentioned that these materials do not generate bacterial resistance as happens with antibiotics, this is because the AgNPs have an effect at different cellular levels such as lysis in the cell wall, damage in the electron transport chain and consequently generation of oxidative stress, enzymatic inhibition and damage to the genetic material (Moghaddam et al., 2015).

In this study it was demonstrated that the culture media and substrate concentration (AgNO3) are factors that influence the production of AgNPs by the filamentous fungus Penicillium purpurogenum CATMC-AH-1, the highest percentage of AgNPs from 2 to 7 $\mathrm{nm}$ was obtained by using the EFS while the highest AgNPs concentration was obtained with the EFC, both with $\mathrm{AgNO}_{3}$ concentration of $2 \mathrm{mM}$. In general, the AgNPs obtained are of small size and potential candidates for evaluation as antimicrobial agents, it would be interesting to evaluate if there is a difference between them in this application, as well as being able to determine the type of molecules that could be involved in the synthesis and stabilization of these nanomaterials optimizing their production to obtain AgNPs of homogeneous size.

\section{ACKNOWLEDGEMENTS}

This research received financial support by Project SIP20160119 and 20171531 of the National Polytechnic Institute.

\section{CONFLICT OF INTEREST}

All the researchers listed as authors of the current study declare that there is no conflict of interests regarding the publication of this manuscript.

\section{REFERENCES}

Abdelghany T.M., Al-Rajhi A.M.H., Abboud M.A.A., Alawlaqi M.M., Magdah A.G., Helmy E.A.M., Mabrouk A.S. 2018. Recent advances in green synthesis of silver nanoparticles and their applications: about future directions. a review. BioNanoScience. 8:5-16.

Ariga K., Ji Q., Mori T., Naito M., Yamauchi Y., Abe H. \& Hill J.P. 2013. Enzyme nanoarchitectonics: organization and device application. Chemical Society Reviews. 42(15): 6322-6345.

Aung K.M.M. \& Ting Y.P. 2005. Bioleaching of spent fluid catalytic cracking catalyst using Aspergillus niger. Journal of Biotechnology. 116:159-170. 
Deng X., Chai L., Yang Z., Tang C., Wang Y. \& Shi Y. 2013. Bioleaching mechanism of heavy metals in the mixture of contaminated soil and slag by using indigenous Penicillium chrysogenum strain F1. Journal of Hazardous Materials. 248-249: 107-114.

Ellstrom M., Shah F., Johansson T., Ahrén D., Persson P., Tunlid A. 2015. The carbon starvation response of the ectomycorrhizal fungus Paxillus involutus. FEMS Microbiology Ecology, 91:1-11.

Gwa V.I \& Abdulkadir K.H. Biological Control Using Trichoderma harzianum against Penicillium purpurogenum, Causal Agent of White Yam Tuber (Dioscorea rotundata Poir) Rb. 2017. Journal of Bioresearch Communications. 1(1):1-6

Husseiny S.M., Salah T.A. \& Anter H.A. 2015. Biosynthesis of size controlled silver nanoparticles by Fusarium oxysporum, their antibacterial and antitumor activities. BeniSuef University Journal of Basic and Applied Sciences. 4(3): 225-231.

Korbekandi H., Ashari Z., Iravani S. \& Abbasi S. 2013. Optimization of Biological Synthesis of Silver Nanoparticles using Fusarium oxysporum. Iranian Journal of Pharmaceutical Research: IJPR. 12(3): 289-98.

Moghaddam A.B., Namvar F., Moniri M., Tahir P., Azizi S. \& Mohamad R. 2015. Nanoparticles Biosynthesized by Fungi and Yeast: A Review of Their Preparation, Properties, and Medical Applications. Molecules. 20: 16540-16565.

Méndez-Zavala A., Contreras-Esquivel J.C., Lara-Victoriano F., Rodríguez-Herrera R., Aguilar C.N.2007. Fungal production of the red pigment using a xerophilic strain Penicillium purpurogenum GH-2. Revista Mexicana de Ingeniería Química. 6(3): 267-273

Narsing-Rao M.P., Xiao M. \& Li W.J. 2017. Fungal and bacterial pigments: Secondary metabolites with wide applications. Frontiers in Microbiology. 8: 1-13.

Nitsche B.M., Jørgensen T.R., Akeroyd M., Meyer V. \& Ram A.F. 2012. The carbon starvation response of Aspergillus niger during submerged cultivation: Insights from the transcriptome and secretome. BMC Genomics. 13(1): 380.

Raza M., Kanwal Z., Rauf A., Sabri A., Riaz S. \& Naseem S. 2016. Size- and ShapeDependent Antibacterial Studies of Silver Nanoparticles Synthesized by Wet Chemical Routes. Nanomaterials. 6(74): 1-15.

Sandoval-Cárdenas D.I. 2012. Uso de hongos microscópicos aislados de muestras ambientales para la producción de nanopartículas de plata. Instituto Politécnico Nacional. Queréaro, México.

Sandoval-Cárdenas I., Gómez-Ramírez M. \& Rojas-Avelizapa N.G. 2017. Use of a sulfur waste for biosynthesis of cadmium sulfide quantum dots with Fusarium oxysporum f. sp. lycopersici. Materials Science in Semiconductor Processing. 63: 33-39. 
Selvam K., Sudhakar C., Govarthanan M., Thiyagarajan P., Sengottaiyan A., Senthilkumar B. \& Selvankumar T. 2017. Eco-friendly biosynthesis and characterization of silver nanoparticles using Tinospora cordifolia (Thunb.) Miers and evaluate its antibacterial, antioxidant potential. Journal of Radiation Research and Applied Sciences. 10(1): 6-12.

Siddiqi K.S. \& Husen A. 2016. Fabrication of Metal Nanoparticles from Fungi and Metal Salts: Scope and Application. Nanoscale Research Letters. 11(1): 98.

Singh P., Kim Y.J., Zhang D. \& Yang D.C. 2016. Biological Synthesis of Nanoparticles from Plants and Microorganisms. Trends in Biotechnology. 34(7): 588-599.

Singh R., Wagh P., Wadhwani S., Gaidhani S., Kumbhar A., Bellare J. \& Chopade B.A. 2013. Synthesis, optimization, and characterization of silver nanoparticles from Acinetobacter calcoaceticus and their enhanced antibacterial activity when combined with antibiotics. International Journal of Nanomedicine. 8: 4277-4290.

Srikar S.K., Giri1 D.D., Pal1 D.B., Mishra P.K., Upadhyay S.N. 2016. Green synthesis of silver nanoparticles: a review. Green and Sustainable Chemistry. 6:34-56

Vahabi K., Mansoori G.A. \& Karimi S. 2011. Biosynthesis of Silver Nanoparticles by Fungus Trichoderma Reesei (A Route for Large-Scale Production of AgNPs). Insciences Journal. 1(1): 65-79.

Vigneshwaran N., Ashtaputre N.M., Varadarajan P.V., Nachane R.P., Paralikar K.M. \& Balasubramanya R.H. 2007. Biological synthesis of silver nanoparticles using the fungus Aspergillus flavus. Materials Letters. 61(6): 1413-1418.

Wei L., Lu J., Xu H., Patel A., Chen Z. \& Chen G. 2016. Silver nanoparticles: synthesis, properties, and therapeutic applications. Drug Discov Today. 20(5): 595-601.

Zhang X., Liu Z., Shen W. \& Gurunathan S. 2016. Silver Nanoparticles: Synthesis, Characterization, Properties, Applications, and Therapeutic Approaches. International Journal of Molecular Sciences. 17: 1534 1-34. 